\title{
LIMA BEAN (Phaseolus lunatus L.) SEEDS EXPOSED TO DIFFERENT SALT CONCENTRATIONS AND TEMPERATURES ${ }^{1}$
}

\author{
MARIA DAS GRAÇAS RODRIGUES DO NASCIMENTO²*, EDNA URSULINO ALVES ${ }^{3}$, MARIA LÚCIA \\ MAURÍCIO DA SILVA ${ }^{2}$, CAROLINE MARQUES RODRIGUES ${ }^{3}$
}

\begin{abstract}
Salinity problems are increasing in the semi-arid regions of northeastern Brazil. Thus, detailed studies of the region's cultured crops, primarily salt-tolerant species, are important. Therefore, the aim of the present study was to evaluate the salt stress tolerance of lima bean (Phaseolus lunatus L.) seeds at different temperatures. This study was conducted in the Seed Analysis Laboratory, Agricultural Sciences Center, Federal University of Paraíba (Areia, PB, Brazil) by using seeds of four lima bean cultivars (Branca, Orelha de Vó, Rosinha, and Roxinha) in a randomized experimental design. Sodium chloride $(\mathrm{NaCl})$ was used as a solute for salt-stress simulation at the following concentrations: 0.0 (control), 1.5, 3.0, 4.5, 6.0, 7.5, and $9.0 \mathrm{dS} \mathrm{m}^{-1}$; temperatures were maintained constant at $25^{\circ} \mathrm{C}, 30^{\circ} \mathrm{C}$, and $35^{\circ} \mathrm{C}$. Germination and vigor tests were performed to evaluate the treatment effects (first count, germination rate index, seedling length, and dry matter). Germination rate of lima bean seeds increased in salt concentrations up to $9 \mathrm{dS} \mathrm{m}^{-1}$, and seeds of Roxinha cultivar exhibited the highest salinity tolerance. The development of lima bean cultivar seedlings was negatively affected at $35^{\circ} \mathrm{C}$ under high-salinity conditions.
\end{abstract}

Keywords: Lima bean. Germination. Vigor. Abiotic stress.

\section{SEMENTES DE Phaseolus lunatus L. SUBMETIDAS A CONCENTRAÇÕES SALINAS E DIFERENTES TEMPERATURAS}

RESUMO - A problemática da salinidade está aumentando cada vez mais nas regiões semiáridas do nordeste brasileiro, por isso estudos aprofundados com culturas cultivadas nessas regiões principalmente que sejam tolerantes a níveis de salinidades são importantes. Nesse sentido, o objetivo com este trabalho foi avaliar à tolerância de sementes de cultivares de feijão-fava (Phaseolus lunatus L.) a condição de estresse salino em diferentes temperaturas. O trabalho foi realizado no Laboratório de Análise de Sementes do Centro de Ciências Agrárias da Universidade Federal da Paraíba, em Areia, PB, com sementes de quatro cultivares de feijão-fava (Branca, Orelha de Vó, Rosinha e Roxinha), em delineamento experimental inteiramente ao acaso. Para simulação do estresse salino, utilizou-se como soluto o cloreto de sódio $(\mathrm{NaCl})$, nas concentrações de 0,0 (testemunha); 1,$5 ; 3,0 ; 4,5 ; 6,0 ; 7,5$ e $9,0 \mathrm{dS} \mathrm{m}^{-1}$ submetidas a temperaturas constantes de 25,30 e $35{ }^{\circ} \mathrm{C}$. Na avaliação do efeito dos tratamentos, realizou-se teste de germinação e vigor (primeira contagem e índice de velocidade de germinação, comprimento e massa seca de plântulas). A germinação de sementes dos cultivares de feijão-fava (Phaseolus lunatus L.) é elevada quando submetidas a concentrações salinas de até $9 \mathrm{dS} \mathrm{m}^{-1}$, sendo as sementes do cultivar Roxinha as mais tolerantes à salinidade simulada com cloreto de sódio. A temperatura de $35{ }^{\circ} \mathrm{C}$ não favorece o desenvolvimento das plântulas em condições salinas para todos os cultivares avaliados.

Palavras-chave: Feijão-fava. Germinação. Vigor. Estresse abiótico.

\footnotetext{
*Corresponding author

${ }^{1}$ Received for publication in $03 / 21 / 2016$; accepted in $08 / 23 / 2016$.

Paper extracted from the dissertation masters of the first author.

${ }^{2}$ Department of Posgraduate in Agronomist, Universidade Federal da Paraíba, Areia, PB, Brazil; graca.agronomia@gmail.com, luciagronomia@hotmail.com.

${ }^{3}$ Department of Fitotecnia, Universidade Federal da Paraíba, Areia, PB, Brazil; ursulinoalves@hotmail.com, maxcarol48@hotmail.com.
} 


\section{INTRODUCTION}

Phaseolus lunatus L. is commonly known as lima bean; however, it is referred to by different named depending on the cultivation regions in Brazil, e.g., feijoal, bonge, mangalô-amargo, fava-Belém, fava-terra, feijão-espadinho, feijão-farinha, feijão fígado de galinha, or feijão-favona (LOPES et al., 2010). This species is economically and socially important, owing to its hardiness with extended harvests during the dry period (AZEVEDO; FRANCO; ARAÚJO, 2003). In northeastern Brazilian, the lima bean is an important alternative income and food source (GUIMARÃES et al., 2007), with a planted area of 24,581 ha producing 7,693-ton annually (IBGE, 2015).

$P$. lunatus is one of the main leguminous plants of the semi-arid regions of northeastern Brazil, including the states of Paraíba, Rio Grande do Norte, Ceará, Sergipe, Piauí, and Minas Gerais. Frequent soil salinization is noted at these locations owing to the elevated salt content of the irrigation water associated with high temperatures and intense evaporation (DJILIANOV et al., 2003).

Among external factors, stress frequently results in negative effects in plants (TAIZ; ZEIGER, 2013) and each stress component affects plant growth depending on various factors such as plant species, cultivar, phenological stage, environment salinity, and stress intensity and duration (CRAMER; ALBERICO; SCHMIDT, 1994). Most culture productivity is also affected by salt, osmotic, and temperature stresses, which has impaired agricultural expansion in various regions worldwide (SONG; LEI; TIAN, 2005).

Salt stress, owing to high sodium or other cation concentrations in solution, affects element availability and thus indirectly affects plant development (ZANANDREA et al., 2006). Germination of seeds exposed to different salt concentrations was used as an indicator of species tolerance to salinity; thus, germination and vigor tests are useful to determine the physiological responses of species under salt stress (DANTAS; RIBEIRO; ARAGÃO, 2005).

Some studies have shown that germination and initial seedling growth were negatively affected by salt stress in some species, e.g., P. vulgaris L. (COELHO et al., 2010; DEUNER et al., 2011) and Albizia lebbeck (L.) Benth. (LIMA et al., 2015).

Therefore, the aim of the present study was to evaluate the salt tolerance of lima bean seeds exposed to salt stress at different temperatures.

\section{MATERIAL AND METHODS}

This study was conducted in the Seed Analysis Laboratory of the Agricultural Sciences
Center of the Federal University of Paraíba, Areia, PB, Brazil, using seeds of four lima bean cultivars (Branca, Orelha de Vó, Rosinha, and Roxinha), obtained from the 2014 yield of Queimadas, PB, Brazil. Seeds were obtained and then taken to the laboratory, where they were homogenized, packed in plastic bags, and refrigerated for 45 days.

Sodium chloride $(\mathrm{NaCl})$ was used as the solute for salt-stress simulation at the following concentrations: 0.0 (control), 1.5, 3.0, 4.5, 6.0, 7.5, and $9.0 \mathrm{dS} \mathrm{m}^{-1}$. Dilution was performed in distilled and deionized water, and the electrical conductivity of the solutions was measured using a conductivity meter. Only distilled and deionized water were used for substrate moistening in the control treatment, and the electrical conductivity values of the $\mathrm{NaCl}$ solutions were obtained using Richards' equation (1954): $\mathrm{SC}=0.001\left(\mathrm{EC}_{\mathrm{S}}-\mathrm{EC}_{\mathrm{an}}\right) \mathrm{EW} / 0.097$, where: $\mathrm{SC}=$ salt concentration $\left(\mathrm{g} \mathrm{L}^{-1}\right) ; \mathrm{ECs}=$ electrical conductivity of the mixture at $25^{\circ} \mathrm{C}\left(\mathrm{dS} \mathrm{m} \mathrm{m}^{-1}\right)$; $\mathrm{EC}_{\mathrm{an}}=$ electrical conductivity of the water $\left(\mathrm{dS} \mathrm{m}^{-1}\right)$; $\mathrm{EW}=$ equivalent weight of the salt, and $0.97=$ estimated purity $(\%)$ of sodium chloride.

For the germination test of each treatment, 200 seeds treated with Captan ${ }^{\circledR}$ fungicide were used (240 $\mathrm{g}$ fungicide $100 \mathrm{~kg}^{-1}$ seeds), and were divided into $4 \times 50$ seed groups and distributed over two paper towel sheets, covered with a third sheet, and wrapped in rolls. The towel paper was moistened using the previously mentioned $\mathrm{NaCl}$ solutions at three times the dry paper towel mass, with no additional moistening. The control treatment was moistened with distilled and deionized water at the same amount. Rolls were packed in $0.04 \mathrm{~mm}$ thick transparent plastic bags to avoid evaporation.

Germination was performed using a Biological Oxygen Demand (B.O.D.) germinator calibrated for $25^{\circ} \mathrm{C}, 30^{\circ} \mathrm{C}$, and $35^{\circ} \mathrm{C}$ constant temperatures, and an 8 -h photoperiod using daylight type fluorescent bulbs $(4 \times 20 \mathrm{~W})$. Evaluations were performed daily after test establishment for 9 days, when the experiment was finished and the following criteria were obtained: number of seeds that emitted primary root and aerial parts (normal seedlings), and percentage of abnormal seedlings (PAS).

The germination rate index (GRI) was calculated during the germination test and daily normal seedling counts were carried out at the same time of the day every day from day 5 to 9 . The index was calculated through Maguire's equation (1962): GRI $\left.=\mathrm{G}_{1} / \mathrm{N}_{1}+\mathrm{G}_{2} / \mathrm{N}_{2}+\ldots+\mathrm{Gn} / \mathrm{Nn}\right) ;$ where: GRI = germination rate index, $\mathrm{G}_{1}, \mathrm{G}_{2}$, and $\mathrm{G}_{\mathrm{n}}=$ number of germinated seeds on the first, second, and last counts, $\mathrm{N}_{1}, \mathrm{~N}_{2}$, and $\mathrm{N}_{\mathrm{n}}=$ number of days from sowing to the first, second, and last counts.

At the end of the experiment, the seedling length was measured for each treatment. Then, they were weighed and packed in Kraft paper bags, and dried using an oven with air circulation and 
exchange at $65^{\circ} \mathrm{C}$ until a constant weight was obtained $(72 \mathrm{~h})$ for dry mass measurement. After drying, samples were weighed using an analytical balance with $0.001 \mathrm{~g}$ accuracy and results were expressed as grams (g).

A randomized experimental design was adopted, and treatments were distributed in a $7 \times 3 \times 4$ factorial arrangement (osmotic potentials temperatures and cultivars) with four repetitions. Obtained data was submitted to variance analysis and converted into $\sqrt{x+0.5}$ through F-Test at 5\% probability for the following variables: germination rate index, dry mass of root and aerial parts, and abnormal plants. Qualitative data was submitted to means tests, whereas quantitative data was evaluated using a polynomial regression analysis through SISVAR ${ }^{\circledR}$ software (FERREIRA, 2007).

\section{RESULTS AND DISCUSSION}

Among lima bean seeds, the Roxinha cultivar presented the highest physiological potential, with better germination and vigor results in the first count. The lowest physiological quality was observed in the Branca cultivar, which presented the lowest value for all evaluated characteristics, except for the germination rate index (Table 1).

Table 1. Initial seed quality of four lima bean (Phaseolus lunatus L.) cultivars characterized by germination (G), first germination count (FGC), germination rate index (GRI), aerial part length (APL), primary root length (RL), aerial part dry mass (APDM), root dry mass (RDM), and abnormal seedlings (PAS).

\begin{tabular}{|c|c|c|c|c|c|c|c|c|}
\hline \multirow{2}{*}{ Cultivar } & G & FGC & \multirow{2}{*}{ GRI } & APL & RL & APDM & RDM & \multirow{2}{*}{ PAS (\%) } \\
\hline & \multicolumn{2}{|c|}{$\%$} & & \multicolumn{2}{|c|}{$\mathrm{cm}$} & \multicolumn{2}{|c|}{ g } & \\
\hline Branca & $95 \mathrm{c}$ & $95 \mathrm{c}$ & $12.40 \mathrm{a}$ & $1.15 \mathrm{c}$ & $1.57 \mathrm{c}$ & $0.721 \mathrm{c}$ & $0.715 \mathrm{c}$ & $1.81 \mathrm{a}$ \\
\hline Orelha de Vó & $97 \mathrm{~b}$ & $97 \mathrm{~b}$ & $12.61 \mathrm{a}$ & $1.18 \mathrm{c}$ & $1.88 \mathrm{~b}$ & $0.827 \mathrm{~b}$ & $0.834 \mathrm{~b}$ & $1.71 \mathrm{a}$ \\
\hline Rosinha & $97 \mathrm{~b}$ & $96 \mathrm{~b}$ & $12.66 \mathrm{a}$ & $1.68 \mathrm{a}$ & $2.23 \mathrm{a}$ & $1.098 \mathrm{a}$ & $1.121 \mathrm{a}$ & $1.61 \mathrm{a}$ \\
\hline Roxinha & $99 \mathrm{a}$ & $98 \mathrm{a}$ & $10.57 \mathrm{a}$ & $1.59 \mathrm{~b}$ & $2.22 \mathrm{a}$ & $0.732 \mathrm{c}$ & $0.717 \mathrm{c}$ & $1.27 \mathrm{~b}$ \\
\hline CV (\%) & 4.1 & 4.52 & 18.17 & 15.92 & 20.23 & 19.17 & 20.45 & 47.22 \\
\hline
\end{tabular}

*Means followed by the same letter in columns do not differ by Scott-Knott's test at $5 \%$ probability.

Seed germination percentage (Figure 1) of the majority of lima bean cultivars was $>96 \%$ at all evaluated temperatures and salt concentrations; however, this value began to decrease for Branca cultivar seeds at $35^{\circ} \mathrm{C}$ and $1.5 \mathrm{dS} \mathrm{m}$. Germination percentage did not change among different concentrations at $25^{\circ} \mathrm{C}$ and $30^{\circ} \mathrm{C}$. These results demonstrate that Branca cultivar seeds are more
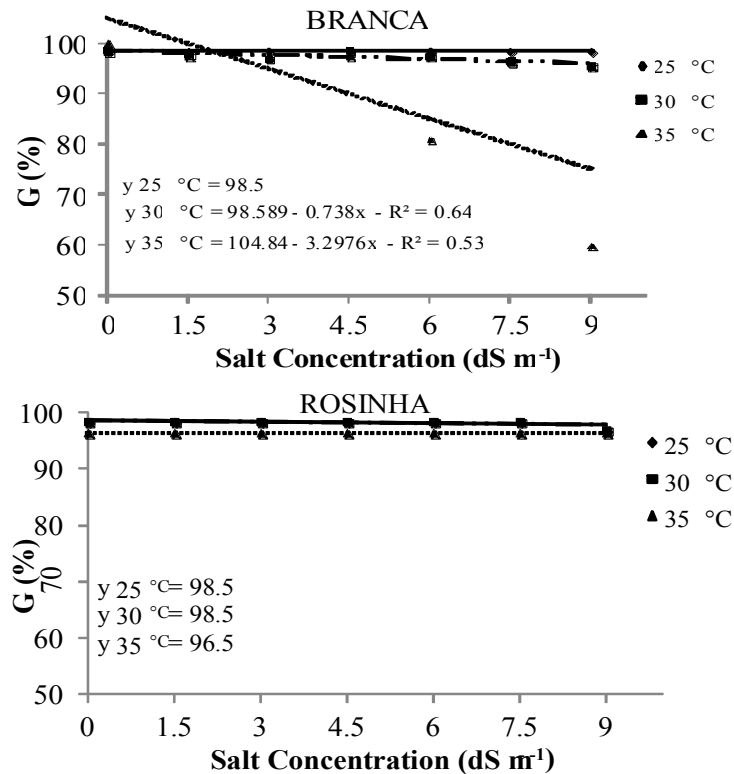

salt-stress sensitive when exposed to higher temperatures, since the salt accumulation in their tissues possibly increases the abscisic acid (ABA) activity, which reduces seed germination.

Yu et al. (2016) evaluated the association of ABA with salinity in Arabidopsis thaliana seeds and observed that ABA negatively affects seeds germination.
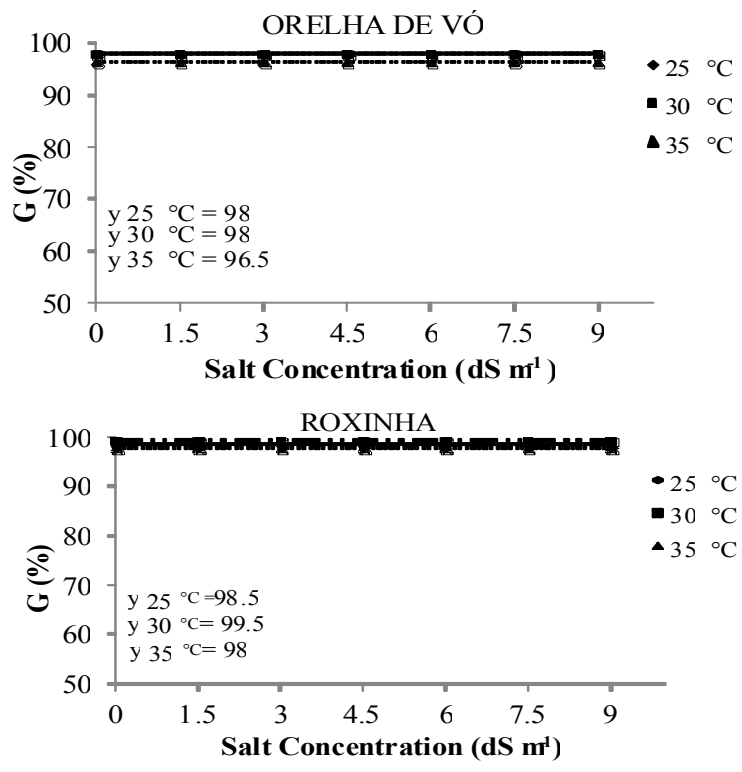

Figure 1. Germination of lima bean (Phaseolus lunatus L.) cultivar seeds under different salt concentrations at different temperatures.

Rev. Caatinga, Mossoró, v. 30, n. 3, p. 738 - 747, jul. - set., 2017 
Plants growing in saline environments withstand low osmotic potential values (solutes), which significantly reduce the water potential of cells and enable an excessive salt entry (TAIZ; ZEIGER, 2013). In addition, metabolite repair or accumulation may occur along the osmotic adjustment, improving germination during stress, e.g., saline and dry periods, and along the entire treatment (HAGHPANAH; YOUNESI; MORADI, 2009).

Another aspect that may be associated with this process is cross-tolerance, which releases stress responses to a specific or various stresses, when the seed is exposed to a specific stress (RIZHSKY; LIANG; MITTLER, 2002). Thus, seed and seedling performance is positively affected by environmental stresses, which can induce cross tolerance and favor the development and performance of mature plants (SCHUCH et al., 2013).

Only the percentage of seeds that germinated was negatively affected in the Branca cultivar at $35^{\circ} \mathrm{C}$, corroborating a study conducted by Larcher (2000), who observed germination delays or a decrease in the number of germinated seeds depending on the salt concentration and species'

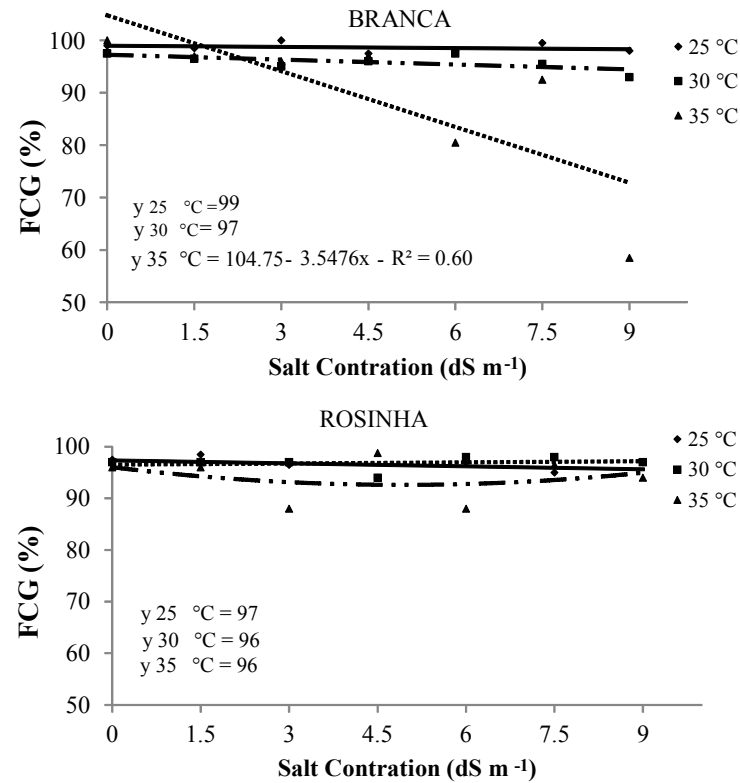

tolerance. Flamboyant seeds (Delonix regia (Bojer ex Hook.) Raf.) presented a maximum emergence percentage of $74 \%$ at $0.5 \mathrm{dS} \mathrm{m} \mathrm{m}^{-1}$ with a progressive decrease at $1.5 \mathrm{dS} \mathrm{m}^{-1}$ and above; however, differences occurred only at $6.0 \mathrm{dS} \mathrm{m}^{-1}$ (NOGUEIRA et al., 2012). Arugula seeds (Eruca sativa Mill.) germinated under saline conditions up to $-0.4 \mathrm{MPa}$, showed a significant germination reduction at higher concentrations (ARAÚJO et al., 2014).

The first germination count data from Branca cultivar seeds only fitted the linear regression model when exposed to $35^{\circ} \mathrm{C}$, with $100 \%$ germination at $0.0 \mathrm{dS} \mathrm{m} \mathrm{m}^{-1}$; however, there was a decrease in germination at salinities above $1.5 \mathrm{dS} \mathrm{m}^{-1}$. An average $97 \%+$ germination was obtained for $25^{\circ} \mathrm{C}$ and $30^{\circ} \mathrm{C}$, thus not fitting any regression models and presenting the highest percentages at $25^{\circ} \mathrm{C}$ (Figure 2). This seeds of cultivars are possibly unable to present satisfactory development under saline conditions and high temperatures.

The first germination count of Orelha de Vó, Rosinha, and Roxinha cultivars seeds exposed to salt concentrations did not fit polynomial regression models and presented averages varying from $93 \%$ to $99 \%$ in each temperature (Figure 2).

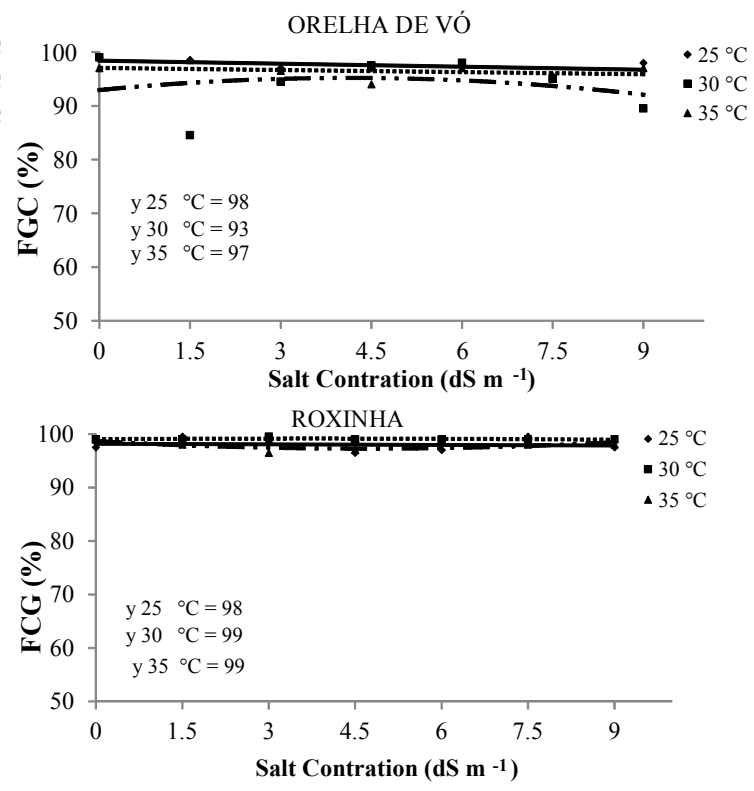

Figure 2. First germination count of lima bean (Phaseolus lunatus L.) cultivar seeds under different salt concentrations at different temperatures.

Most studies involving salinity reported that the presence of salt affects the water potential of the soil and/or substrates, resulting in a decreased soil-seed surface potential gradient, and restraining water absorption (LOPES; MACEDO, 2008). Excessive diluted salt cause salinity and toxicity problems, impair water absorption, and result in cellular and molecular damage in the majority of glycophytes (TAIZ; ZEIGER, 2013). Thus, it is important to understand the survival ability of these plants under saline conditions. One of the most used methods for determining high salt tolerance is the first germination count percentage (OLIVEIRA et al., 2007). Metabolite repair or accumulation could occur along an osmotic adjustment with enhanced germination under stress, e.g., salinity and dry periods, during the entire treatment (HAGHPANAH; YOUNESI; MORADI, 2009).

Salt concentrations that impair lima bean growth vary widely among varieties depending on salt type, exposure period, and development stage (DEUNER et al., 2011). The germination rate index 
of the cultivar seeds did not fit polynomial regression models when exposed to salt concentrations; however, Branca, Orelha de Vó, and
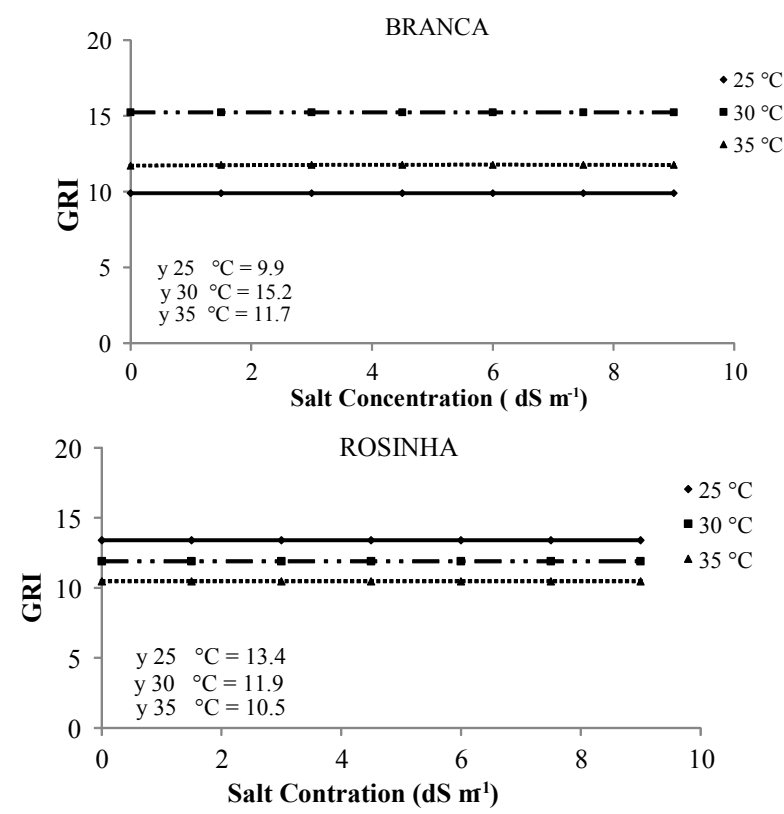

Rosinha cultivar seeds presented the highest values at the following temperatures 30 (15.2); 35 (11.7), and $25^{\circ} \mathrm{C}$ (13.4) (Figure 3).
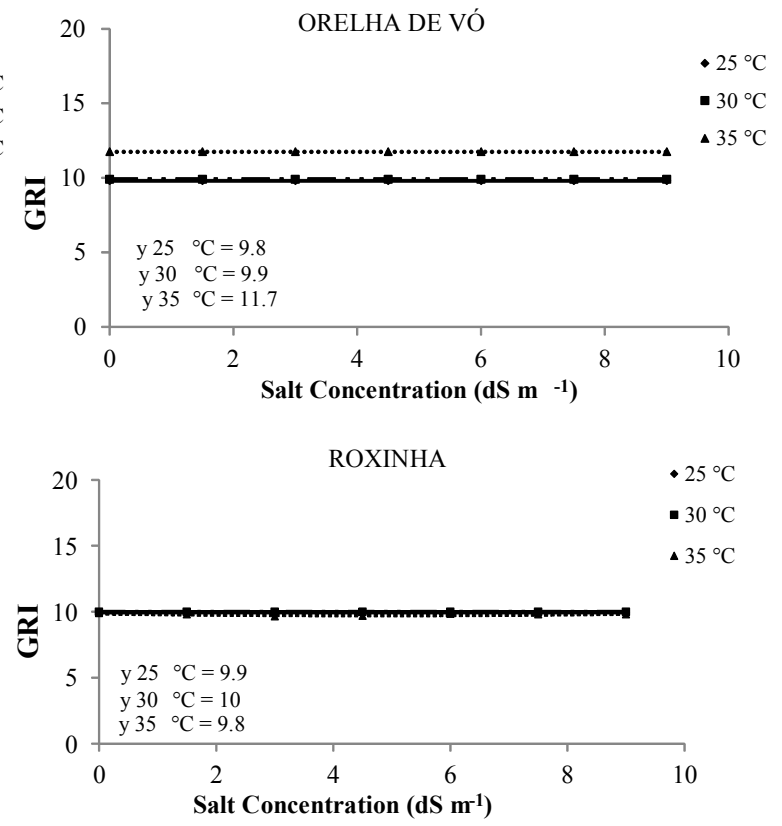

Figure 3. Germination rate index of lima bean (Phaseolus lunatus L.) cultivar seeds under different salt concentrations at different temperatures.

The germination rate index is proportional to seed vigor and these plants are the most salinity-sensitive; thus, even the lowest salt concentration may result in a decreased in the production quantity and quality of seeds (LOPES et al., 2014). Temperature may also cause stress and lead to differences in germination and vigor, determined by first count and germination rate index, and depending on the seed's physiological quality, i.e., its physiological maturity degree during harvest, or membrane deterioration level (MARINI et al., 2012).

Seed vigor, evaluated using the germination rate index, of various species exposed to salt stress was negatively affected, e.g., fava d'anta (Dimorphandra mollis Benth.) (MASETTO et al., 2014), niger (Guizotia abyssinica (L.f.) Cass.) (GORDIN et al., 2012), and cucumber (Cucumis sativus. L.) (MATIAS et al., 2015).

The initial aerial length of Branca cultivar seedlings (Figure 4), of which seeds were exposed to $30^{\circ} \mathrm{C}$ in accordance to the derivative of function, was $1.44 \mathrm{~cm}$; there was a $1.87 \mathrm{~cm}$ increase at 0.0 concentration and $35^{\circ} \mathrm{C}$ with a posterior decrease, whereas length was uniform at all salt concentrations at $25^{\circ} \mathrm{C}$ with $1.3 \mathrm{~cm}$ average. Orelha de Vó cultivar presented average values of $1.27 \mathrm{~cm}$ at $30^{\circ} \mathrm{C}$, $1.13 \mathrm{~cm}$ at $35^{\circ} \mathrm{C}$ and $1.11 \mathrm{~cm}$ at $25^{\circ} \mathrm{C}$, and small aerial part length increases associated with salt concentration increases; Rosinha and Roxinha cultivars presented a short length $(<1.1 \mathrm{~cm})$.

In addition to damaging the physico-chemical properties of soil, sodium salt excess leads to a generalized reduction of plant growth that causes serious losses in agriculture (CAVALCANTE et al., 2010). Furthermore, it may lead to the inhibition of growth in most species (TOBE; XIAOMING; OMASA, 2000) owing to the osmotic effect, causing physiological drought and toxicity, resulting from protoplasm's ion concentration.

These results are observed in most species owing to a salt excess in the rhizosphere of seedlings, which resulted in lower water availability and water absorption by roots; thus, osmotic pressure increases and inhibits cell expansion and division (MAHAJAN; TUTEJA, 2005).

The root length of Branca cultivar seedlings was determined through the derivative of the function: $2.25 \mathrm{~cm}$ at $3.13 \mathrm{dS} \mathrm{m} \mathrm{m}^{-1}$ and $25^{\circ} \mathrm{C}$. A decrease was observed at $30^{\circ} \mathrm{C}$ and higher concentrations with a $0.95 \mathrm{~cm}$ average, while length reached $2.18 \mathrm{~cm}$ at $35^{\circ} \mathrm{C}$ (Figure 5). Orelha de Vó cultivar's length remained constant among all concentrations at $25^{\circ} \mathrm{C}$ and $35^{\circ} \mathrm{C}$ and 2.32 and $1.44 \mathrm{~cm}$, respectively. A minimum of $0.063 \mathrm{~cm}$ was observed at $30^{\circ} \mathrm{C}$ and $0.084 \mathrm{dS} \mathrm{m} \mathrm{m}^{-1}$. Regarding Rosinha and Roxinha cultivars, uniformity was observed at 25 and $35^{\circ} \mathrm{C}$ ( 3 and $1.52 \mathrm{~cm}$; and 2.92 and $1.82 \mathrm{~cm}$, respectively); however, differences were observed between both cultivars at $30^{\circ} \mathrm{C}$, reaching the minimum length value at $1.26 \mathrm{dS} \mathrm{m}^{-1}$ (Rosinha) and the maximum of $2.52 \mathrm{~cm}$ at $6.83 \mathrm{dS} \mathrm{m}^{-1}$ (Roxinha). 

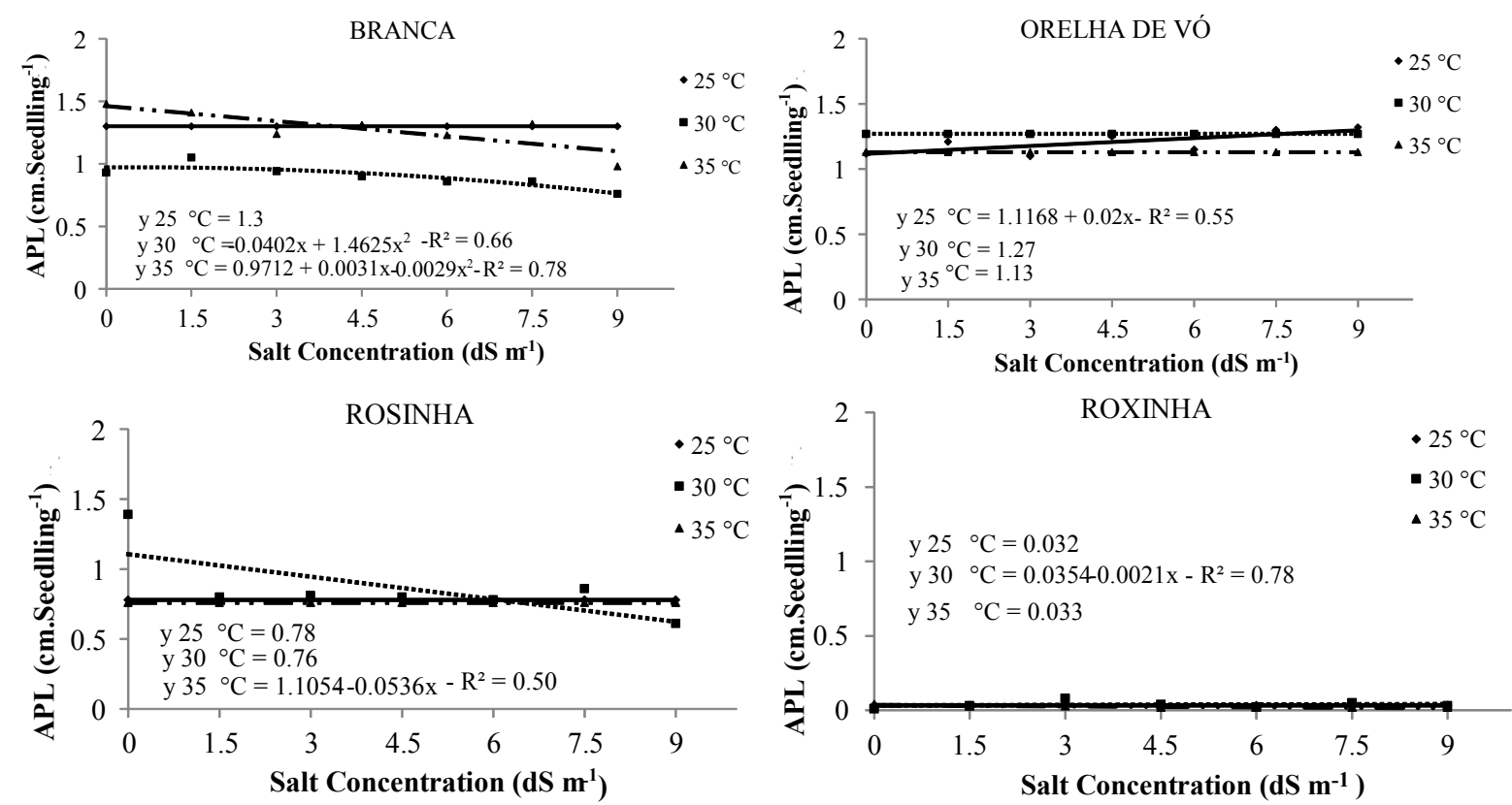

Figure 4. Aerial part length of lima bean (Phaseolus lunatus L.) cultivar seedlings obtained from seeds exposed to different salt concentrations at different temperatures.
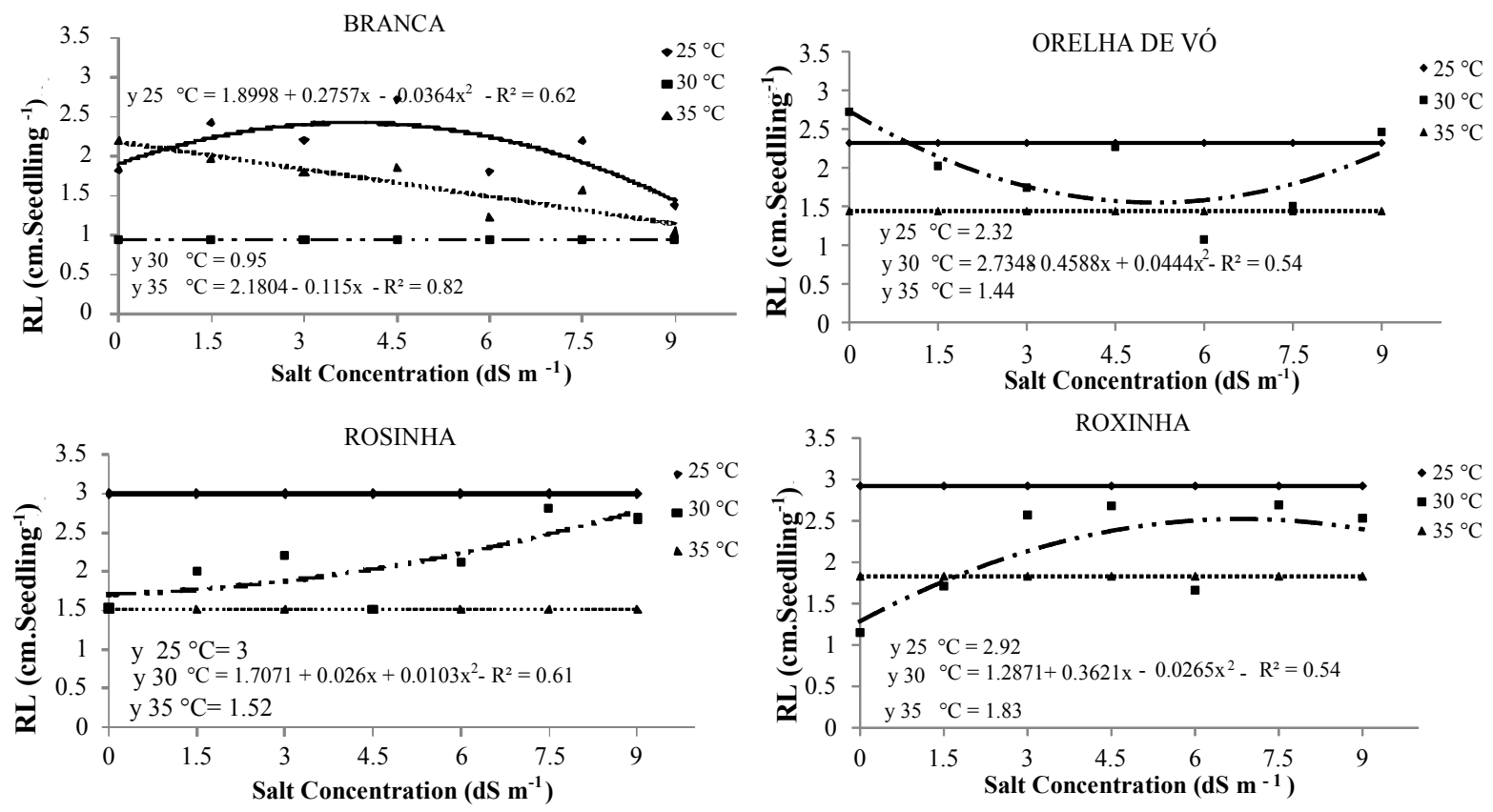

Figure 5. Primary root length of lima bean (Phaseolus lunatus L.) cultivar seedlings obtained from seeds exposed to different salt concentrations at different temperatures.

Studies evaluating watermelon (Citrullus lanatus (Thunb.) Matsum. and Nakai) seeds exposed to salt stress using $\mathrm{NaCl}$ reported longer seedling root lengths until the $-8.0 \mathrm{MPa}$ potential with a subsequent decrease, owing to salt becoming harmful for this species (SOUSA; SILVA; SIMON, 2009).

Aerial part and root dry mass of lima bean cultivar seedlings were not affected by increases of salt concentrations to which their seeds were exposed; however, temperatures caused a slight variation $(0.71$ and $1.11 \mathrm{~g}$; and 0.71 and $1.17 \mathrm{~g})$ in both mentioned varieties. Under these conditions, a decrease in biomass was observed, because all cultivars presented dry seedlings weights below $3 \mathrm{~g}$ (Figures 6 and 7).

Melon cultivar (Cucumis melo L.) seedlings exposed to salt stress presented a reduction of wet and dry mass at salinity levels above $4 \mathrm{dS} \mathrm{m}^{-1}$; however, there was a lower reduction for Sancho and Gaúcho cultivars, which are more salt stress tolerant (ARAGÃO et al., 2009). The aerial part of the dry mass of the flamboyant (Delonix regia (Bojer ex Hook.) Raf.) decreased as salinity levels increased, and a greater decrease was observed at $10.8 \mathrm{dS} \mathrm{m}^{-}$ $\mathrm{NaCl}$ (CHAVES et al., 2013) and above. 

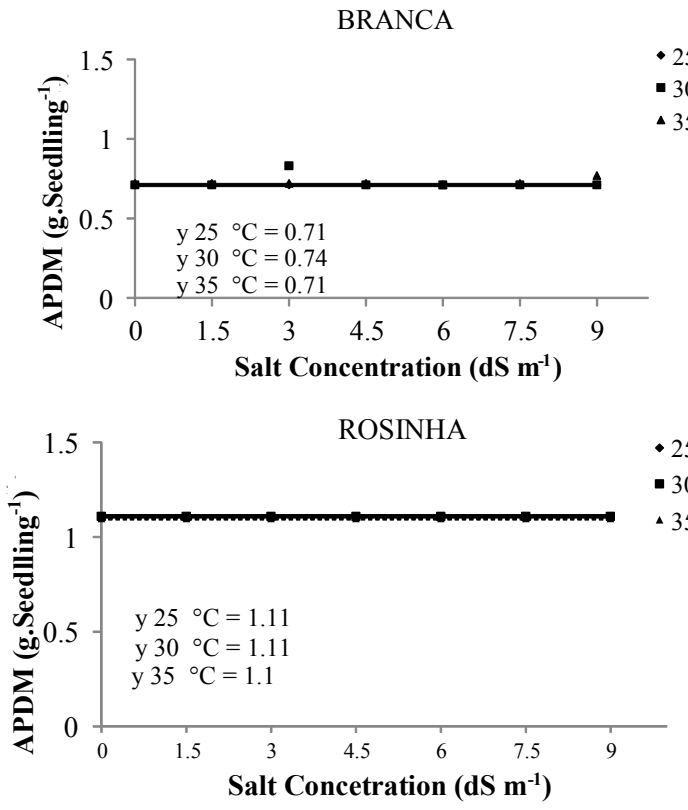

ORELHA DE VÓ
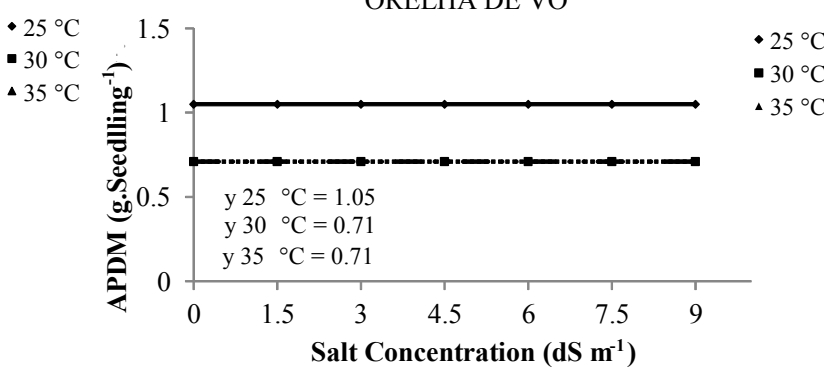

ROXINHA

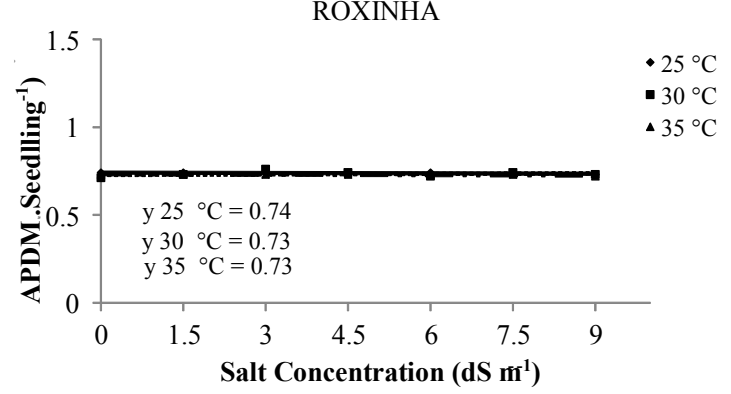

Figure 6. Aerial part of the dry mass of lima bean (Phaseolus lunatus L.) cultivar seedlings obtained from seeds exposed to different salt concentrations at different temperatures.
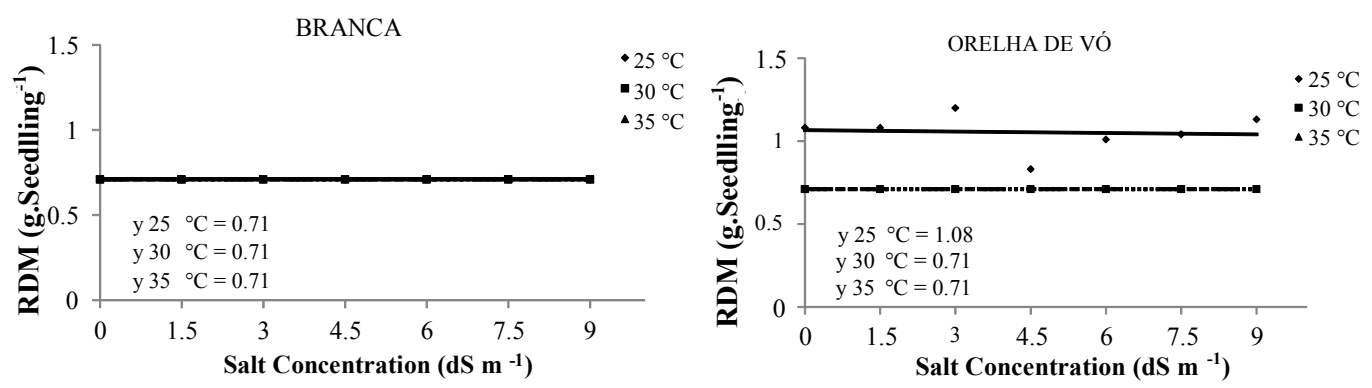

ROSINHA
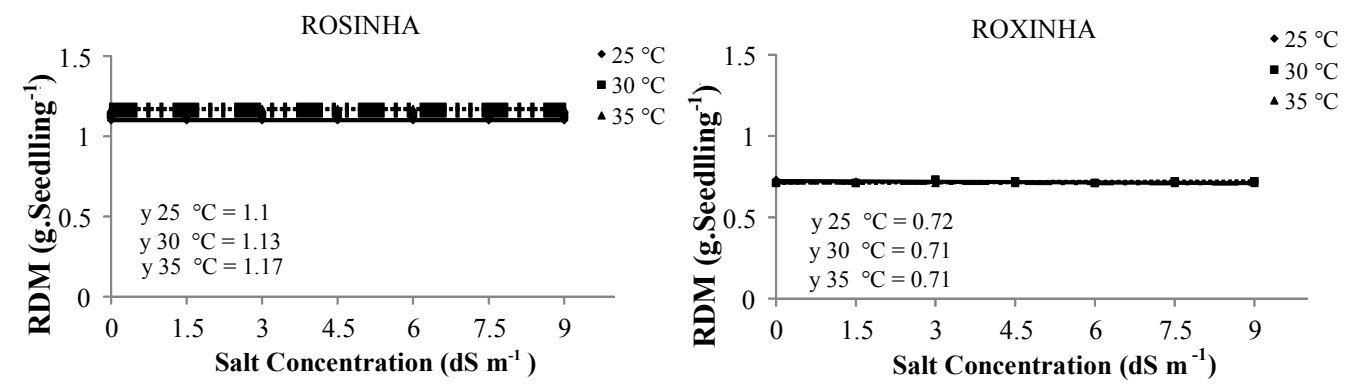

Figure 7. Root dry mass of lima bean (Phaseolus lunatus L.) cultivar seedlings obtained from seeds exposed to different salt concentrations at different temperatures.

The percentage of abnormal seedlings was $1 \%$ for the Branca cultivar at $30^{\circ} \mathrm{C}$ and $35^{\circ} \mathrm{C}$ and at least 2 and $1 \%$ abnormal seedlings were observed at 2.0 and $0.31 \mathrm{dS} \mathrm{m}^{-1}$ (Figure 8). Respective 1.5 and $2 \%$ were obtained for Orelha de Vó cultivar at $25^{\circ} \mathrm{C}$ and $35^{\circ} \mathrm{C}$, whereas a maximum of $1.80 \%$ was obtained at $30^{\circ} \mathrm{C}$ and $5.89 \mathrm{dS} \mathrm{m}^{-1}$. Uniformity was observed in the Rosinha cultivar under different salt concentrations at different temperatures: $1.28 \%$ at $25^{\circ} \mathrm{C}, 1.36 \%$ at $30^{\circ} \mathrm{C}$, and $2.44 \%$ at $35^{\circ} \mathrm{C}$. The minimum percentage of Roxinha cultivar was $1 \%$ at $30^{\circ} \mathrm{C}$ and $4.46 \mathrm{dS} \mathrm{m}^{-1}$; percentages were constant for both other temperatures at all salt concentrations: $1.36 \%$ at $25^{\circ} \mathrm{C}$ and $1.5 \%$ at $35^{\circ} \mathrm{C}$.

The highest percentage of abnormal watermelon (Citrullus lanatus (thumb) Masnf.) plants was observed at 16.7 and $22.7 \mathrm{dS} \mathrm{m}^{-1}$ osmotic potentials, with $\mathrm{NaCl}$ as the solute (TORRES, 2007). The -1.2 MPa osmotic potential dramatically reduced the percentage of normal corn plants owing to decreased water absorption by seeds (KAPPES et al., 2010). 

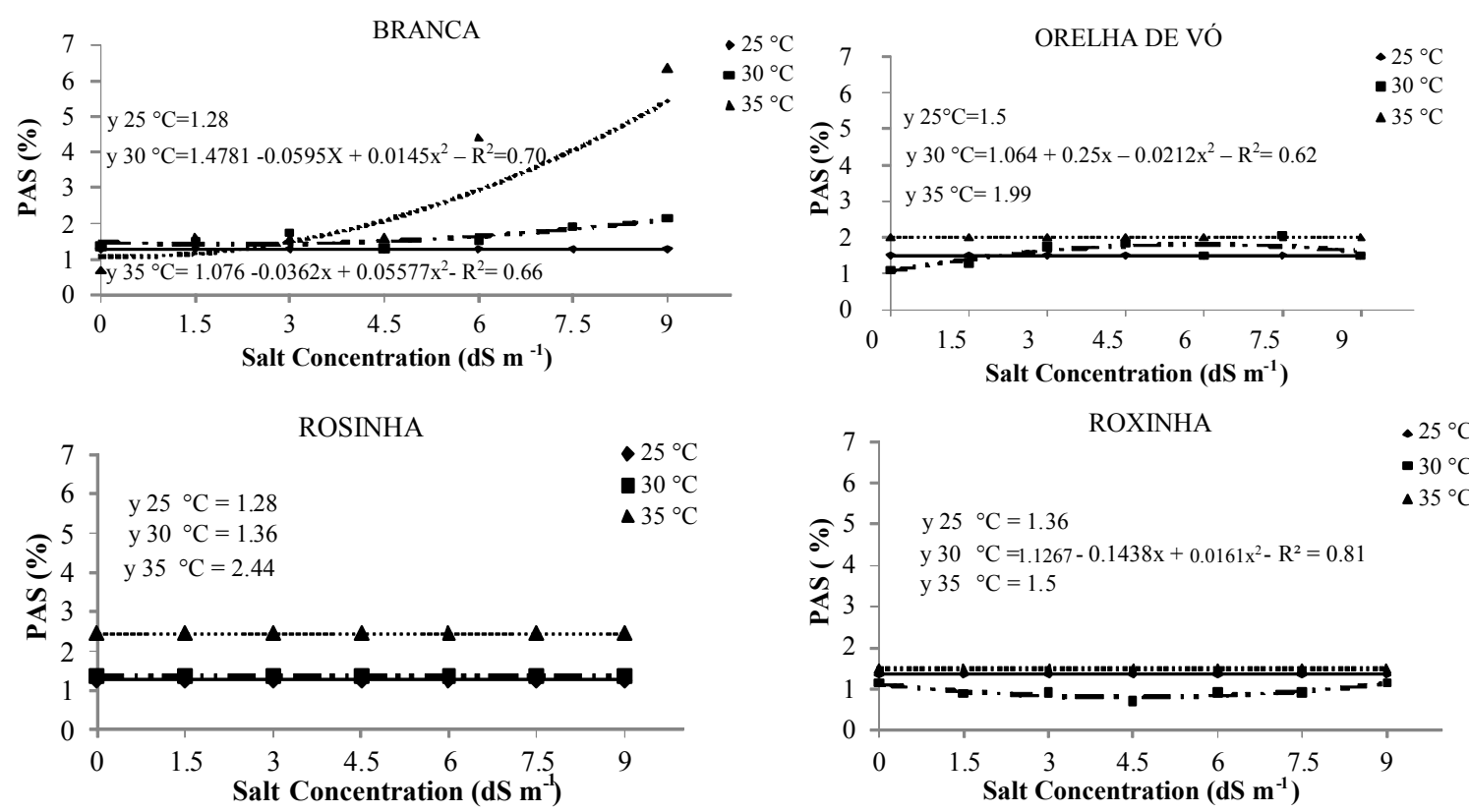

Figure 8. Abnormal seedlings of lima beans (Phaseolus lunatus L.) obtained from seeds exposed to different salt concentrations at different temperatures.

\section{CONCLUSION}

Lima bean cultivar seed germination is not affected by salt concentrations up to $9 \mathrm{dS} \mathrm{m}^{-1}$; Roxinha cultivar seeds are the most tolerant to the simulated sodium chloride salinity; and seedling development of all evaluated cultivars was not enhanced under saline conditions at $35^{\circ} \mathrm{C}$.

\section{REFERENCES}

ARAGÃO, C. A. et al. Avaliação de cultivares de melão sob condições de estresse salino. Revista Caatinga, Mossoró, v. 22, n. 2, p. 161-169, 2009.

ARAÚJO, M. L. et al. Avaliação do efeito do estresse salino sobre o desenvolvimento inicial da rúcula. Colloquium Agrariae, Presidente Prudente, v. 10, n. 1, p. 1-8, 2014.

AZEVEDO, J. N.; FRANCO, L. J. D.; ARAÚJO, R. O. C. Composição química de sete variedades de feijão-fava. Teresina: Embrapa Meio-Norte, 2003. 4 p. (Embrapa Meio-Norte Comunicado Técnico, 152).

CAVAlCANTE, L. F. et al. Fontes e níveis da salinidade da água na formação de mudas de mamoeiro cv. Sunrise solo. Semina: Ciências Agrárias, Londrina, v. 31, n. 4, p. 1281-1290, 2010.

CHAVES, A. P. et al. Efeito da salinidade na emergência e desenvolvimento de plântulas de flamboyant. Agropecuária Científica no Semiárido, Patos, v. 9, n. 3, p. 119-123, 2013.
COELHO, D. L. M. et al. Estresse hídrico com diferentes osmóticos em sementes de feijão e expressão diferencial de proteínas durante a germinação. Acta Scientiarum. Agronomy, Maringá, v. 32, n. 3, p. 491-499, 2010.

CRAMER, G. R.; ALBERICO, G. J.; SCHMIDT, C. Salt tolerance is not associated with the sodium accumulation of two maize hybrids. Australian Journal of Plant Physiology, Melbourne, v. 21, n. 5, p. 675-692, 1994.

DANTAS, B. F.; RIBEIRO, L. S.; ARAGÃO, C. A. Physiological response of cowpea seeds to salinity stress. Revista Brasileira de Sementes, Pelotas, v. 27, n. 1, p. 144-148, 2005.

DEUNER, C. et al. Viabilidade e atividade antioxidante de sementes de genótipos de feijão-miúdo submetidos ao estresse salino. Revista Brasileira de Sementes, Pelotas, v. 33, n. 4, p. 711-720, 2011.

DJILIANOV, D. et al. Nodulation under salt stress of alfalfa lines obtained after in vitro selection for osmotic tolerance. Plant Science, California, v. 165, n. 4, p. 887-894, 2003.

FERREIRA, D. F. Sisvar: Versão 5.1 (Build 72). DEX/UFLA. 2007.

GORDIN, C. R. B. et al. Estresse salino na germinação de sementes e desenvolvimento de plântulas de niger (Guizotia abyssinica (L.f.) Cass.). Acta Botanica Brasilica, Belo Horizonte, v. 26, n. 4, p. 966-972, 2012. 
GUIMARÃES, W. N. R. et al. Caracterização morfológica e molecular de acessos de feijão-fava (Phaseolus lunatus L.). Revista Brasileira de Engenharia Agrícola e Ambiental, Campina Grande, v. 11, n. 1, p. 37-45, 2007.

HAGHPANAH, A.; YOUNESI, O.; MORADI, A. The effect of priming on seedling emergence of differentially matured sorghum (Sorghum bicolor L.) seeds. Journal of Applied Sciences Research, Mousa, v. 5, n. 7, p. 729-732, 2009.

INSTITUTO BRASILEIRO DE GEOGRAFIA E ESTATÍSTICA - IBGE. 2013. SIDRA - Sistema IBGE de recuperação automática. Rio de Janeiro: Instituto Brasileiro de Geografia e Estatística. Disponível em <http://www.sidra.ibge.gov.br>. Acesso em: 21 jul. 2015.

KAPPES, C. et al. Germinação, vigor de sementes e crescimento de plântulas de milho sob condições de déficit hídrico. Scientia Agrária, Curitiba, v. 11, n. 2, p. 125-134, 2010.

LARCHER, W. Ecofisiologia vegetal. 2. ed. São Carlos, SP: RIMA, 2000. 531p.

LIMA, M. F. P. et al. Emergência e crescimento inicial de plântulas de albízia submetidas à irrigação com água salina. Revista Brasileira de Engenharia Agrícola e Ambiental, Campina Grande, v. 19, n. 2, p. 106-112, 2015

LOPES, A. C. A. et al. Diversidade genética. In: ARAÚJO, A. S. F.; LOPES, A. C. A.; GOMES, R. L. F. (Eds.). A cultura do feijão-fava na região Meio-Norte do Brasil. Teresina: EDUFPI, 2010, v. 1, p. $45-72$.

LOPES, J. C.; MACEDO, C. M. P. Germinação de sementes de couve chinesa sob influência do teor de água, substrato e estresse salino. Revista Brasileira de Sementes, Pelotas, v. 30, n. 3, p. 79-85, 2008.

LOPES, K. P. et al. Salinidade na qualidade fisiológica em sementes de Brassicasoleracea L. var. itálica. Semina: Ciências Agrárias, Londrina, v. 35, n. 5, p. 2251-2260, 2014.

MAGUIRE, J. D. Speed of germination-aid in selection and evaluation of seedling emergence and vigor. Crop Science, Madson, v. 2, n. 2, p. 176-177, 1962.

MAHAJAN, S.; TUTEJA, N. Cold, salinity and drought stresses: an overview. Archives of Biochemistry and Biophysics, San Francisco, v. 444, n. 2, p. 139-158, 2005

MARINI, P. et al. Alterações fisiológicas e bioquímicas em sementes de arroz submetidas ao estresse térmico. Revista Ciência Agronômica, Fortaleza, v. 43, n. 4, p. 722-730, 2012.

MASETTO, T. E. et al. Germinação de sementes de Dimorphandra mollis Benth.: efeito de salinidade e condicionamento osmótico. Brazilian Journal of Biosciences, Porto Alegre, v. 12, n. 3, p. 127-131, 2014

MATIAS, J. R. et al. Germinação de sementes de pepino cv. Caipira em condições de estresse hídrico e salino. Revista Sodebras, São Paulo, v. 10, n. 113, p. 33-39, 2015

NOGUEIRA, N. W. et al. Efeito da salinidade na emergência e crescimento inicial de plântulas de flamboyant. Revista Brasileira de Sementes, Lavras, v. 34, n. 3, p. 466-472, 2012.

OLIVEIRA, A. M. et al. Salinidade na germinação e desenvolvimento de plântulas de aroeira (Myracroduon urundeuva Fr All). Revista Caatinga, Mossoró, v. 20, n. 2, p. 39-42, 2007.

RICHARDS, L. A. Diagnosis and improvement of saline and alkali soils. Washington: USA, 1954. 160 p. (USDA Agricultural Handbook, 60).

RIZHSKY, L.; LIANG, H.; MITTLER, R. The combined effect of drought stress and heat shock on gene expression in tobacco. Plant Physiology, New York, v. 130, n. 3, p. 1143-1151, 2002.

SCHUCH, L. O. B. et al. Sementes: Produção, qualidade e inovações tecnológicas. 1. ed. Pelotas, RS: EGU, 2013. 571 p.

SONG, S. Q.; LEI, Y. B.; TIAN, X. R. Proline metabolism and cross-tolerance to salinity and heat stress in germinating wheat seeds. Russian Journal of Plant Physiology, Moscow, v. 52, n. 6, p. 793-800, 2005.

SOUSA, M. A.; SILVA, D. C.; SIMON, G. A Desempenho de plântulas de melancia submetidas a diferentes níveis de potencial osmótico. Global Science and Technology, North Carolina, v. 3, n. 2, p. 8-19, 2009.

TAIZ, L.; ZEIGER, E. Fisiologia vegetal. 5. ed. Porto Alegre, RS: Artmed, 2013. 819 p.

TOBE, K.; XIAOMING, L.; OMASA, K. Seed germination and radicle growth of a halophyte, Kalidium caspicum (Chenopodiaceae). Annals of Botany, Leicester, v. 85, n. 3, p. 391-396, 2000.

TORRES, S. B. Germinação e desenvolvimento de plântulas de melancia em função da salinidade. 
Revista Brasileira de Sementes, Lavras, v. 29, n. 3, p. 77-82, 2007.

YU, Y. et al. Salt stress and ethylene antagonistically regulate nucleocytoplasmic partitioning of COP1 to control seed germination. Plant Physiology, Beijing, v. 170 , n. 4, p. 2340-2350, 2016.

ZANANDREA, I. A. et al. Efeito da salinidade sob parâmetros de fluorescência em Phaseolus vulgaris. Revista Brasileira de Agrociência, Pelotas, v. 12, n. 2, p. 157-161, 2006. 